\title{
The combine structure of Industrial-Academic-Research (lar) In art design specialty application-oriented undergraduate education
}

\author{
Zou Kejin ${ }^{1,2, a}$ \\ ${ }^{1}$ School of Fine art, Jilin Engineering Normal University, Changchun 130052 China \\ ${ }^{2}$ School of Fine Art, Northeast Normal University, Changchun 130052, China
}

\begin{abstract}
An increasing number of application-oriented art majors are admitted to college and universities. An important adjustment and change of higher education in its construction and features impels our country came into a time of popularized higher education. The Personnel training system and the quality of talents training have attracted great attentions from the society more than ever before. The significance of IAR system are: reforming the model of talents cultivation, consummating the system of education; rebuilding the current teaching status, perfecting teaching process; reforming practice environment, developing the school-enterprise cooperation model and improving the quality of teaching.
\end{abstract}

\section{Introduction}

An increasing number of application-oriented art majors are admitted to college and universities with the development of economic in our country. An important adjustment and change of higher education in its construction and features impels our country came into a time of popularized higher education. The Personnel training system and the quality of talents training have attracted great attentions from the society more than ever before.

Art design specialized teaching is a systematical project, the key point of exploration on IAR in art design specialty application-oriented undergraduate education teaching model, which is also the first thing that all teachers should realized is the changing of teaching and educational concepts. Higher education places have no longer been ivory-tower academic like secondary institutions which is far away from regular life. Talents of application oriented art design universities and college must pay much attention to cultivate students' ability of self-study, independently thinking and solving problems, as well as practicing. Teachers must raise the awareness that emphasizing the training of students' all round development, combing the personality development and the innovation conscious.

\section{Reforming the model of talents cultivation, consummating the system of education, to deepen the structure of industrial - academic - research (iar) integration}

The definition of Application-oriented Undergraduate cultivation is distinct from technologists and academics type cultivation. Applied talents are the people who have stronger abilities of practicing and more direct application knowledge. However, applied talents' cultivation system of our country is not consummate enough, $t$ Structure of IAR has not been clearly defined, the curriculum setting model tends to be confused, and the teaching object remains obscure. All these factors lead to the insignificance of characteristics of applied talents cultivation, the deficiency of aiming education idea. The way of curriculum setting has far to go.

Teaching reform of art design specialty in colleges and universities should be based on the foundation of curriculum. The Application-oriented under graduation education must be separated individually from the research-oriented under graduation education, and must go out of traditional education model such as "theory before practice". Applied Talents are the people who are creative enough and have abundant theory knowledge and strong practice ability. The foundation is theory curriculum and the core is professional practice. Theory courses should be organized well is on the point of teaching design, Changing the conservative scientific teaching system into the designed by modular system, is on the point of teaching content. Art design specialty has its own characteristics, the pursuit of logic and deliberation is not as strong as the science and engineering specialty. Therefore, trying to teaching under the modular system will be a great advantage.

\section{Reforming the current teaching status, consummating the teaching process, to}

\footnotetext{
a Corresponding author: guotianbao1999@126.com
} 


\section{impel the structure of industrial - academic - research (iar) integration}

Teaching is the vital part of undergraduate education. Because of the knowledge of art design is updating in a high speed, and the market flexibility is outstanding, art teaching should keep pace with the times. Information of society and requirements of art talents should be reflected in the teaching process in time, which means art design teaching materials should be improved on the aspects of timeliness, contemporaneity and application. Also, the improvements of teaching quality as well as theory and practice teaching capability are important.

\subsection{Construction of teaching materials}

Construction of art design teaching materials has always been a concerning subject by university teachers and professional scholars. Most of the present textbooks have the characteristics of unitary which means they are tedious and not be able to highlight the key points. Those textbook have no teaching contents to be referenced or to be practically thought to students. The isolated ideals and thoughts lead to the antiquated structure and content. Textbooks are limited in openness and can not combine with market application. The existence of those problems provides both wilder expanding spaces and sever challenges for art teaching. Those problems require professional teaching materials should follow the demands of teaching reformation, follow the market demands for talents in art area. Furthermore, the starting point of our teaching materials would be higher and broader, our objective is to leading the art teaching reformation, try to make a big step to make the change happen. High-speed updating of knowledge leads to the high-speed updating of teaching material. Complicated phenomenon will unavoidably emerge in the market-oriented economy current. The applied-oriented art design teaching materials should clearly reflect the latest teaching idea and design thinking also should have a zero distance contact with the market application. Guiding ideologies was proposed by the teaching materials published by People' Fine Art Publishing House, National Vocational and Technical Normal Colleges say, " $20 \%$ foundational theory $+30 \%$ latest teaching ideals $+50 \%$ guiding practice design". They also proposed a teaching materials' compiling structures ideal says "Establishing a multidimensional cross cube structure, attaching great importance to design process, teaching process, practice training, and sketch drawing." all these ideals make a great example. Teaching materials are an outline and basis for teachers and an effectual way for students.

\subsubsection{The construction of a "Double - Qualified Teacher" System}

Teachers are the major essential of teaching process. The quality and achievements of teaching largely depends on the teaching level. The standard of evaluation and employment of professional title in universities and colleges, especially for those application-oriented universities and colleges, was based on the educational background, academic degree and professional titles. Besides, practical experience and manual ability should also be one of the most important evaluation criteria. A professional application-oriented art design teacher should do a good job both in the enterprises and class, which means to become a "double-qualified teacher" type talent.

a) The following conducts should be performed according to the characteristics of art major:

b) Encouraging teachers to participate in international academic exchanges and support them with further training to improve their professional skills.

c) Professional teachers should be posted to companies doing some visiting and part-time job.

d) Inviting established artists, designers and company executives to give some academic lectures and do the teaching of part-time. This will extend the vision of teachers, make them closely follow the steps of social demands and improve their capability of design.

In order to achieve the construction of "double-qualified teacher", teachers' researches and developments of project design creations must be strongly supported. Universities should establish a practical platform for social enterprise to exchange and consulate.

\subsubsection{The construction of teaching process}

The teaching orientation of application-oriented art universities and colleges is to combine the theory and practice, the theory of design is based on the professional study of practicing, and will be applied to guiding the practice finally. The interactivity of "teaching" and "learning" reflect obviously during art design profession education process. The foundation of tradition education is "knowledge first", and "theory rules", teachers always emphasized the value of objective theories and the knowledge points are taught in order of logic strictly to students. However, this kind of tradition way has not paid much attention to subjective values which made students not be able to cultivate the interest of humanistic implication of art, the essential of art design, design thinking and the healthy development of modern society. Teachers focus on teaching while ignore leading. The teaching system is inflexible and tedious. Students only pay attention to the acquirement of technology and knowledge during the whole time but the can not combine what they have learnt with the practice, never say neither the application of new knowledge nor cultivation of creative thinking.

\section{Reforming the practice training environment, consummating the school-enterprise cooperation model, to pursue the structure of industrial -academic -research (iar) integration}

The practice training courses of art design 
application-oriented undergraduate education is an effectual way to combined with production and study, students would appeared in person, they are under the guidance of teachers and masters in the factory, also ,there is many opportunities for them to do the word by hands. However, this is not easy to be put into practice during the actual teaching process. Insufficient attention is given to it by teachers, students are also lack of interest. This situation implicitly shows that, the subjective cognizance of cultivating application-oriented talents model education has not been attached much weight, the objective has not been clarified, besides, there are many objective problems remain to be solved.

\subsection{The mutual benefit solution to formalism phenomenon of off-campus practice bases}

Because of the formalism phenomenon of off-campus practice bases, interns could not obtain practical experience from the realistic production. The major tasks of above bases are production and manufacture, and aim at profit creation. However, interns could not satisfy the requirements and fulfill the responsibilities of regular employees from short-term training. Another reason for the formalism is that redundant interns would obstacle the working progress, which leads to the inefficiency of employees. Thus enterprises are unwilling to provide effective opportunities of internship. It is essential to reform the mode of practical training. According to the principle of equality and mutual benefit, enterprises should create more internship opportunities and improve social responsibilities for professional training. Meanwhile, universities should strengthen the professional qualities and skills of students, which benefits mutually and perfect the university-enterprise cooperation education mode.

\subsection{The lack of interests in practical training for interns}

In the studying progress, students could obtain theoretical knowledge step by step in logical order. On the contrary, employees should achieve constant and single assignments due to the production chain of enterprises, which is based on working flows and require employees to work repeatedly. In the short-term, there is no willingness or opportunities for interns to concentrate in unattractive a practical process, which leads to the situation those interns, could not be acquainted with the whole manufacture flow and are not willing to work repeatedly. It requires that industry-academy cooperation should provide more practical chances for interns rather than treat these students as cheap labor forces and compel them to operate repetitively. Enterprises should pay attention to cultivate professionals and provide a platform for interns' realistic working experiences.

There is a mechanism of industry - university research cooperation, which is integrity. 'University' is foundation, 'industry' is applying and 'research' is promotion. It is necessary to develop these three aspects simultaneously. Besides the combination of theory and practice in the undergraduate education in art and design, students should be trained and obtain the creative spirit with subjectivity. Artistic designing should not get rid of abundant humanities knowledge, and the practical could not be equal to the craftsman, which requires that this field should be combined with social culture and strengthen students' consciousness of innovation. In order to cultivate professional talents, the essential task is the transformation and reformation in the educational teaching management. Higher education is no longer ivory-tower academic researching method but the updating knowledge mode. Education institutions should concentrate on the ability of self-learning and self-updating, which is more likely to be accepted by enterprises in the future.

\section{References}

1. J.A. Thompson, The Modern Idea of the University. Peter-Lang Publishing, Inc, (1984).

2. J.D.A. Detlefsen, Proquest, Umi Dissertation Publishing, (1988).

3. J. Li, VS Verlag für Sozialwissenschaften (2012).

4. D. Phillips, Routledge, (1995).

5. A.H. Chamberlain, BiblioLife (2009).

6. S.W. Art Education, Scholastic and Industrial. Gale, Sabin Americana (2012). 